\title{
EXTERIORIZAÇÃO DA VIDA E ALIENAÇÃO NOS MANUSCRITOS ECONÔMICO- FILOSÓFICOS DE 1844 DE KARL MARX
}

\author{
THE EXTERIORIZATION OF LIFE AND THE ALIENATION IN KARL MARX'S 1844 ECONOMIC AND \\ PHILOSOPHIC MANUSCRIPTS
}

Monica Hallak Martins da Costa*

\section{RESUMO}

Os Manuscritos de 1844 de Karl Marx são frequentemente compreendidos como textos superados pelo suposto Marx "maduro" e "científico", sendo, portanto, retratados como uma curiosidade do passado "filosófico" do autor. O presente artigo pretende demonstrar que a superação fundamental com o idealismo já havia se concretizado por ocasião da redação dos Manuscritos, assim como colocar em evidência a categoria central e fio condutor desses rascunhos: aquela da exteriorização da vida - tanto em seus aspectos abstratos, quanto na configuração da vida social nos marcos do capitalismo. Assim, propõe-se neste texto argumentar em favor da continuidade e aprofundamento da abordagem da alienação do trabalho como tema central em Marx desde 1844 até o fim da vida. Este artigo é resultado da pesquisa na qual busquei averiguar, através da análise imanente dos Manuscritos de 1844 de Marx, a pertinência da proposta interpretativa de Lukács em Para uma ontologia do ser social (1981), em que situa objetivação e alienação como complexo unitário distinto do fenômeno do estranhamento. $\mathrm{Na}$ análise do texto de Marx tal compreensão não se confirma, o que não compromete a riqueza e pertinência da abordagem do autor húngaro.

PALAVRAS-CHAVE: Alienação. Apropriação humana. Capitalismo. Exteriorização. Ser social.

\section{ABSTRACT}

Karl Marx's 1844 Manuscripts are frequently regarded as outdated texts if compared to other works written by a more "mature" and "scientific" Marx. Economic and Philosophic Manuscripts are thus seen as a curiosity from Marx's philosophical past. This paper aims at demonstrating that Marx's idealism had already been consolidated at the time Manuscripts was written. It also aims at highlighting Marx's Manuscritps most important feature: the exteriorization of life in its abstracts aspects as well as in the configuration of social life as a part of Capitalism. Thus, this text proposes to develop arguments that aim to attest the continuity and deepening of the approach to the alienation of labor as a central theme in Marx from 1844 to his very last days. This paper is the outcome of a research in which I sought to check the relevance of Lukács's interpretative proposal in Ontology of Social Being (1981), through analyzing Marx's 1844 Manuscripts. Lukács situates objectification and alienation as a unitary complex that should be regarded distinct from the phenomenon of estrangement. Lukács's diferentiation cannot be confirmed in Marx's Manuscripts, a fact that does not diminishes or compromises the richness and pertinence of the Hungarian's work and approach.

KEY-WORDS: Alienation. Appropriation of human life. Capitalism. Exteriorization. Social being.

\footnotetext{
*Doutora. Professora do Curso de Servico social da PUC Minas. E-mail: monicahallak@uol.com.br.
} 


\section{INTRODUÇÃO}

Em 1932 vêm a público os textos conhecidos hoje como Manuscritos econômicofilosóficos. Redigidos no decorrer do ano de 1844 formam, com alguns outros trabalhos, um conjunto que compreende a fase decisiva que marcará todo o itinerário posterior de Marx. Com efeito, o pensamento próprio de Marx se instaura enquanto tal a partir de três críticas ontológicas desencadeadas pela crítica à política, resultado de uma revisão da Filosofia do direito de Hegel empreendida por Marx em meados de 1843. No prefácio de 1859, de Para a crítica da economia política, Marx resume os resultados desse estudo de 1843 no qual situa a relação entre estado e sociedade civil, rompendo com a especulação ao denunciar a inversão que esta opera quando parte da "ideia como origem ou princípio de entificação do multiverso sensível" (CHASIN, 1995, p. 357).

Em1843 é clara a ruptura com a especulação que se desenvolveu a partir dos primeiros delineamentos da crítica à política que se tornará evidente em A questão judaica e nas Glosas críticas ao artigo "O rei da Prússia e a reforma social" por um prussiano, nas quais a afirmação da ontonegatividade da política é explícita.

A terceira crítica se estabelece, segundo o próprio depoimento de Marx, em consonância com as duas anteriores: "Minha investigação [de 1843] desembocou no seguinte resultado: relações jurídicas, tais como formas de estado, não podem ser compreendidas nem por si mesmas, nem a partir do chamado desenvolvimento geral do espírito humano, mas pelo contrário, elas se enraízam nas relações materiais da vida, cuja totalidade foi resumida por Hegel sob o nome de 'sociedade civil', seguindo os ingleses e os franceses do século XVIII, a anatomia da sociedade civil dever ser procurada na economia política" (MARX, 1974, p.135).

Os Manuscritos são o primeiro trabalho em que Marx se debruça sobre o vasto e denso terreno da sociedade civil, estendendo "o âmbito da análise desde a raiz ao todo da mundaneidade, natural e social, incorporando toda gama de objetos e relações" (CHASIN, 1995, p. 379). Não são, portanto, anotações arbitrárias sem relação com o conjunto de seu pensamento. Ao contrário, se configuram ao mesmo tempo como resultado e ponto de partida de um modo peculiar e original de reflexão sobre a vida humana.

Estas poucas linhas, que pretendem contextualizar minimamente o lugar dos Manuscritos no itinerário de Marx, são certamente insuficientes para trazer para o leitor atual uma ideia, 
genérica ao menos, do impacto causado pelo descobrimento desses escritos em meados do século XX. Para este fim, a transcrição do depoimento de um dos decifradores dos Manuscritos, é, sem dúvida, mais eficaz. Vejamos como se expressa Lukács a respeito desses rascunhos: "pela primeira vez na história da filosofia, as categorias econômicas aparecem como categorias da produção e reprodução da vida humana, tornando assim possível uma descrição ontológica do ser social sobre bases materialistas" (LUKÁCS, 1979, p.14-5). De fato é esta descrição que encontramos nos Manuscritos e é preciso que se registre aqui o reconhecimento da contribuição de Lukács na elucidação das bases ontológicas do pensamento de Marx. O trabalho do grupo de pesquisa responsável pela publicação desses artigos não seria possível sem os seus indicativos, o que não significa que se limite às argumentações do filósofo húngaro. Ao contrário, as pesquisas mais recentes do grupo, bem como as publicações da última década de vida do prof. Chasin, apontam discordâncias e superações em relação a Lukács. De todo modo, o texto apresentado a seguir é fruto em primeiro lugar de suas indicações, em segundo, da tenacidade do professor Chasin que dedicou sua vida à redescoberta de Marx e com o qual tive o privilégio de trabalhar e, finalmente, da enorme paciência da Professora Ester Vaisman, minha orientadora, maior responsável pela efetivação desta pesquisa.

Apesar dos resultados divergentes, as diretrizes básicas do artigo que se segue são as indicadas por Lukács na citação acima. Tanto é assim que o texto se inicia com os lineamentos mais gerais encontrados nos Manuscritos sobre a produção e reprodução da vida humana.

\section{A EXTERIORIZAÇAO DA VIDA HUMANA}

Ao considerar os aspectos gerais da produção, tal como Marx os tematiza nos Manuscritos, destaca-se, antes de mais nada, o caráter relacional de toda a objetividade, presente desde logo nos fenômenos da natureza. Mas, imediatamente, Marx situa a distinção da objetividade humana, que se afirma reproduzindo o homem como ser social, pois a própria relação com a natureza se realiza a partir do vínculo entre os homens.

O caráter social da produção humana se expressa, em primeiro lugar, no carecimento, na especificidade das necessidades humanas, pois, como afirma Marx, "nem os objetos humanos são os objetos naturais, tais como se oferecem imediatamente, nem o sentido humano tal como é 
imediata e objetivamente é sensibilidade humana, objetividade humana" (MARX, p.1972, p. 138, tradução nossa). Na abordagem marxiana, portanto, natureza e sentido se transfiguram em novas objetividades ao se tornarem humanos.

Desse modo, a universalidade da apropriação humana se manifesta precisamente no fato de toda natureza aparecer ao homem como instrumento e matéria de sua atividade genérica. Em outras palavras, enquanto ser social, o homem transforma continuamente a natureza em ser para si, em natureza para o homem, fazendo-a emergir como objetividade social. Vejamos como Marx se expressa a esse respeito:

Da mesma forma que as plantas, os animais, os minerais, o ar, a luz, etc. constituem do ponto de vista teórico uma parte da consciência teórica, seja enquanto objeto da ciência da natureza, seja como objeto da arte (sua natureza inorgânica espiritual que é o meio de subsistência intelectual que o homem deve primeiramente preparar para o gozo e a assimilação), assim também constituem do ponto de vista prático uma parte da vida e da atividade humanas. (MARX, 1972, p. 61 - tradução nossa).

Vê-se que os elementos naturais são constitutivos da consciência, justamente porque são objetos da vida e da atividade humanas. Mas, enquanto tais, precisam ser preparados pelo homem para sua própria assimilação. Nesse preparo, os elementos naturais se convertem para o homem em parte da consciência teórica, o que significa que eles se transformam em objeto da ciência da natureza e da arte. Assim, nas mãos humanas, a objetividade natural se transfigura em objetividade social a partir da atividade genérica na qual "o homem se apropria de seu ser universal de forma universal, isto é, como homem total". Segundo Marx, essa apropriação se realiza através dos atributos sensíveis do homem:

Cada uma de suas relações humanas com o mundo - ver, ouvir, cheirar, saborear, sentir, pensar, observar, perceber, querer, atuar, amar - em resumo, todos os órgãos de sua individualidade, como órgãos que são imediatamente sociais em sua forma, são em seu comportamento objetivo, em seu comportamento para com o objeto, a apropriação de efetividade humana, seu comportamento frente ao objeto é a manifestação da efetividade humana, eficácia humana e sofrimento humano, pois o sofrimento humanamente entendido é o gozo próprio do homem. (MARX, 1972, p. 91, tradução nossa).

O pensamento, portanto, não aparece como a primeira, nem a única forma de apropriação da objetividade sensível. Ao contrário, o comportamento do homem frente ao objeto é algo "tão múltiplo como são as determinações essenciais e atividades humanas" (MARX, 1972, p. 9, 
tradução nossa). Assim, pode-se dizer que a apropriação humana é universal porque seu sofrimento é universal, pois a vida em sociedade abre um campo de possibilidades de carecimentos, e satisfações de carecimentos, infinitos. Mas esse horizonte infinito é sensível. É o constante fazer-se homem do homem: este ser que produz a objetividade social na forma da exterioridade sensível e da sua própria sensibilidade. Como afirma Marx: "O olho fez-se um olho humano, assim como seu objeto se tornou um objeto social humano, vindo do homem para o homem" (MARX, 1972, p. 9, tradução nossa), pois o objeto apropriado pelo homem se converte em objetividade social. Do mesmo modo os órgãos dos sentidos humanos, nessa apropriação, transformam-se continuamente em sentido universal.

Assim, "carecimento e gozo perderam sua natureza egoísta e a natureza perdeu sua mera utilidade, ao se converter a utilidade em utilidade humana" (MARX, 1972, p. 91, tradução nossa), pois o carecimento humano se satisfaz na apropriação humana e, portanto, universal, não somente para o ser individual, mas para o gênero. Com isso, "o sentido e o gozo dos outros homens se converteram em minha própria apropriação" (MARX, 1972, p. 91, tradução nossa), propiciando para a atividade e para os sentidos um vasto campo de atuação concreta, pois

\footnotetext{
além destes órgãos imediatos se constituem, então, órgãos sociais, na forma da sociedade; assim, por exemplo, a atividade imediatamente na sociedade com os outros etc. se converte em órgão de minha exteriorização de vida (Lebensäusserung) e um modo de apropriação da vida humana. (MARX, 1972, p. 92, tradução nossa).
}

Desse modo, o sentido e o gozo dos outros homens, ou seja, a vida social, aparece ela mesma como apropriação de cada homem, pois posso me apropriar do modo de apropriação do outro: posso ouvir com os outros, ver com os olhos dos outros, constituir assim meus próprios órgãos dos sentidos a partir da sensibilidade do outro.

Por outro lado, a própria vida social, a atividade social torna-se órgão por excelência da exteriorização da vida humana, pois, para além dos órgãos dos sentidos imediatamente físicos (que são sociais em sua forma), o sentido e o gozo dos outros homens são a forma do humano se expressar.

Assim, a apropriação humana é universal porque a apropriação de todos os homens se converte em apropriação de cada homem e vice-versa, o objeto de cada apropriação particular é ao mesmo tempo, apropriação universal. Nesse sentido, Marx afirma: 
enquanto de um lado, para o homem em sociedade, a efetividade objetiva se configura em geral como efetividade de suas próprias forças essenciais, todos os objetos se lhe apresentarão como objetivação de si próprio, como objetos que confirmam e realizam sua individualidade, como seus objetos, isto é, o objeto vem a ser ele mesmo. (MARX, 1972, p. 92, tradução nossa).

Mas "como vem a ser seu, depende da natureza do objeto e da natureza da força essencial que a ela corresponde, pois precisamente a determinidade dessa relação constitui o modo particular e real da afirmação" (MARX, 1972, p. 92, tradução nossa). Ou seja, na realidade concreta, a apropriação é uma relação que envolve o objeto em sua especificidade e a força essencial humana em sua capacidade particular de apropriação. Como se vê, Marx não prioriza o pensamento ou a consciência como uma capacidade de apropriação acima das outras, mas considera a capacidade singular, em seu conjunto, como expressão das forças humanas materializadas nos próprios sentidos, sentidos estes, que são no seu entender, "sociais em sua forma".

Cada uma de suas forças essenciais é uma forma de o homem se apropriar da objetividade exterior, portanto também outra face de sua universalidade. Esta é a expressão da sociabilidade na qual o sentido e o gozo de cada homem são apropriados por todos os homens (e vice-versa) e se manifestam, em primeiro lugar, na universalidade da natureza que se converte em corpo inorgânico do homem - o que só acontece porque o padecimento humano é universal, e se satisfaz a partir da atividade sensível na qual cada órgão do sentido é uma força essencial capaz de se apropriar da objetividade exterior de uma maneira particular. A esse respeito, Marx afirma ainda:

subjetivamente considerado: é primeiramente a música que desperta o sentido musical do homem; para o ouvido não musical a mais bela música não tem sentido algum, não é objeto, porque meu objeto só pode ser a confirmação de uma de minhas forças essenciais, isto é, só é para mim na medida em que minha força essencial é para si, como capacidade subjetiva, porque o sentido do objeto para mim (somente tem um sentido a ele correspondente) chega justamente até onde chega meu sentido; por isso também os sentidos do homem social são distintos dos do não social. (MARX, p. 1972, p. 93, tradução nossa).

Por outro lado, mas na mesma linha de reflexão, Marx complementa:

É somente graças à riqueza objetivamente desenvolvida da essência humana que a riqueza da sensibilidade humana subjetiva é inicialmente desenvolvida e produzida, que

Sapere aude - Belo Horizonte, v. 9 - n. 18, p. 61-78, jul./Dez. 2018 - ISSN: 2177-6342 
o olho percebe a beleza da forma, em resumo, que os sentidos tornam-se capazes do gozo humano, tornam-se sentidos que se confirmam como forças essenciais humanas. (MARX, 1972, p. 93, tradução nossa).

A sensibilidade humana subjetiva é, portanto, produto do intercâmbio entre os homens, pois "não só os cinco sentidos, como também os chamados sentidos espirituais, os sentidos práticos (vontade, amor etc.), em uma palavra, o sentido humano, a humanidade dos sentidos, constituem-se unicamente mediante o modo de existência de seu objeto, mediante a natureza humanizada" (MARX, 1972, p. 93, tradução nossa). A objetivação da vida humana produz, assim, simultaneamente, objetividades sociais exteriores ao homem e o próprio homem como ser objetivo a partir da relação dos homens entre si com a natureza humanizada. Esta, enquanto objeto do homem, é a própria sociedade, é o homem mesmo em sua expressão genérica. A sensibilidade humana se constitui somente no interior dessas condições, pois, segundo Marx, a "formação dos cinco sentidos é um trabalho de toda história universal até nossos dias" (MARX, 1972, p. 94, tradução nossa).

Segundo Marx, portanto, a relação do ser social com a natureza diferencia-se da circularidade natural em função da universalidade da apropriação humana. A análise da categoria da exteriorização da vida nos Manuscritos encontra-se no interior dessa argumentação. Ela aparece associada necessariamente ao movimento efetivo, sensível da atividade. Segundo as próprias palavras de Marx:

[...] que o homem seja um ser corpóreo, dotado de forças naturais, vivo efetivo, sensível, objetivo significa que tem como objeto de seu ser, de sua exteriorização de vida (Lebensäusserung), objetos efetivos, sensíveis, ou que só em objetos reais, sensíveis, pode exteriorizar sua vida. Ser objetivo, natural, sensível e ao mesmo tempo ter fora (äusser) de si objeto, natureza, sentido, ou inclusive ser objeto, natureza e sentido para um terceiro se equivalem. (MARX, 1972, p. 136, tradução nossa).

E assim ocorre mesmo quando se trata do pensar, pois "o elemento da exteriorização da vida (Lebensäusserung) do pensamento - a linguagem - é natureza sensível" (MARX, 1972, p. 97, tradução nossa), visto que somente em sua manifestação efetiva torna real o pensamento. Desse modo, para Marx, o que torna o homem homem são suas exteriorizações, entendidas como expressões objetivas, como ato sensível. Nesse sentido, ele afirma que "o homem rico é, ao mesmo tempo, o homem carente de uma totalidade de exteriorização de vida (Lebensäusserung), 
o homem no qual sua própria efetivação existe como necessidade interna, como carência" (MARX, 1972, p. 136, tradução nossa).

Nas passagens reproduzidas acima, é evidente a ausência da categoria da alienação (Entäusserung). Ela aparece associada ao processo de objetivação em outros momentos do texto de Marx de 1844, especialmente quando se trata da crítica à Fenomenologia de Hegel e a alguns aspectos da economia política. Para Marx, aliás, essas duas abordagens colocam-se sob o mesmo ponto de vista: concebem "o trabalho como a essência do homem que se afirma a si mesmo "mas só veem "o lado positivo do trabalho, não seu lado negativo" (MARX, 1972, p. 133, tradução nossa).

Por parte de Hegel, essa compreensão do trabalho apenas em seu lado positivo se apoia na sua concepção do homem como "ser não-objetivo, espiritualista" (MARX, 1972, p. 97, tradução nossa). Para Hegel, o movimento por excelência da vida humana é o movimento do espírito que se baseia na superação da consciência por parte da autoconsciência. Segundo Marx, a "essência humana, o homem, equivale, para Hegel, à autoconsciência" (MARX, 1972, p. 134, tradução nossa).

Marx resume o movimento de superação do objeto da consciência na formulação hegeliana, situando oito passos que consolidam o processo. Importa para a análise empreendida aqui o segundo: "2) a alienação (Entäusserung) da autoconsciência põe a coisidade (dingheit)" (MARX, 1972, p. 135, tradução nossa). A respeito deste ponto, Marx esclarece:

[...] posto que o homem = autoconsciência, assim sua essência objetiva alienada (entäussertes), ou a coisidade (o que para o homem é objeto, e só é verdadeiramente objeto essencial aquilo que é sua essência objetiva. Ora, posto que não se toma o homem efetivo enquanto tal como sujeito, portanto, tampouco a natureza - o homem é a natureza humana -, mas somente a abstração do homem, a autoconsciência, a coisidade só pode ser a autoconsciência alienada [entausserte]) é = autoconsciência alienada (entäusserten), a coisidade é posta por essa alienação (Entäusserung). (MARX, 1972, p. 135 , tradução nossa).

Entre parênteses Marx coloca a contraposição, que é particularmente esclarecedora quando se trata de Hegel, entre o homem tomado como ser objetivo e como abstração, mostrando que o segundo só pode pôr a coisidade abstrata, pois a autoconsciência é uma abstração do homem. Desse modo, a coisidade que ela põe é a autoconsciência alienada, ou seja, é ela mesma posta para fora de si. Marx prossegue afirmando que é 
[...] perfeitamente compreensível um ser vivo, natural, provido e dotado de forças essenciais objetivas, isto é materiais, ter objetos reais e naturais de seu ser e igualmente sua auto-alienação (Selbstentäusserung) ser o assentamento (Setzung) de um mundo real, mas sob a forma de exterioridade (Äusserlichkeit), como um mundo objetivo que não pertence ao seu ser e que ele não domina. (MARX, 1972, p. 135, tradução nossa).

Desse modo, segundo Marx, quando se trata do ser objetivo a autoalienação é o assentamento de um mundo real sob a forma da exterioridade, ou seja, como algo distinto de si, como um ser objetivo diante de outro ser objetivo. A autoconsciência, por seu turno, por meio de sua alienação põe "apenas a coisidade, isto é, apenas uma coisa abstrata, uma coisa da abstração, e não uma coisa efetiva", pois todo movimento se desenvolve na consciência, no interior de si mesmo.

Com o ser objetivo o movimento se passa de outro modo. Segundo Marx:

Quando o homem real, corpóreo, de pé sobre a terra firme e aspirando e expirando todas ao forças naturais, assenta suas forças essenciais reais e objetivas como objetos estranhos mediante sua alienação (Entäusserung), o assentar (Setzen) não é o sujeito, é a subjetividade de forças essenciais objetivas, cuja ação por isso deve ser objetiva. O ser objetivo atua objetivamente e não atuaria objetivamente se o objetivo não estivesse na determinação de seu ser. $\mathrm{O}$ ser objetivo cria e assenta apenas objetos, porque ele próprio é posto por objetos, porque é originariamente natureza. (MARX, 1972, p. 136, tradução nossa).

Marx demonstra nessa passagem que, ao contrário do que Hegel acredita, "no ato de assentar, não cai, pois, de sua 'atividade pura' em uma criação do objeto, senão que seu produto objetivo apenas confirma sua atividade objetiva, sua atividade como atividade de um ser natural e objetivo" (MARX, 1972, p. 137, tradução nossa).

Contrapondo-se a Hegel, portanto, Marx se utiliza dos termos do seu interlocutor para demonstrar que o homem como ser objetivo assenta suas forças objetivas no objeto concreto, real, exterior, atualizando suas forças objetivas em algo fora de si, o que na versão hegeliana se dá mediante a alienação do sujeito.

A alienação aparece nesses trechos situando a contraposição entre "assentamento de um mundo real sob a forma da exterioridade" e a alienação da autoconsciência que põe apenas a coisidade, uma coisa da abstração. 
Não se trata, portanto, de uma identificação entre objetivação e alienação. Ao contrário, Marx busca situar a distinção do movimento real, que se passa no mundo objetivo, daquele descrito por Hegel, que se desenvolve no pensamento.

Do lado da Economia Política, Marx denuncia que o trabalho é considerado apenas como produtor da riqueza exterior. Na primeira parte do Terceiro Manuscrito, na qual analisa a doutrina fisiocrática, Marx afirma que com a fisiocracia "a essência subjetiva da riqueza transfere-se para o trabalho.” (MARX, 1972, p. 81, tradução nossa), pois com ela "a terra somente é para o homem mediante o trabalho, mediante a agricultura". Este é o lado positivo da doutrina que representa um avanço em relação ao mercantilismo "que não conhecia outra existência da riqueza senão o metal nobre" (MARX, 1972, p. 82, tradução nossa). Mas, para os fisiocratas,

[...] a agricultura é o único trabalho produtivo. O trabalho ainda não é entendido na sua universalidade e abstração; está ligado ainda a um elemento natural particular, à sua matéria; é ainda reconhecido sob um modo de existência particular determinado pela natureza. Por isso é ainda uma alienação (Entäusserung) determinada, particular do homem, da mesma maneira que seu produto é apreendido ainda como uma riqueza determinada, que depende mais da natureza do que do próprio trabalho. (MARX, 1972, p.82, tradução nossa).

Desse modo, a terra, segundo tal doutrina, é ainda o único objeto sobre o qual o homem se exterioriza, libera suas energias essenciais ou, na versão da economia política, produz riqueza; e, desta maneira, a matéria natural aparece ainda como uma fonte de riqueza maior que o próprio trabalho.

Por isso, Marx afirma que para os fisiocratas somente "propriedade fundiária se converte em homem alienado (entäusserten)" (MARX, 1972, p. 82, tradução nossa), ou seja, em homem que objetiva suas forças essenciais no objeto, na riqueza exterior. Mas somente a terra é objeto de apropriação e exteriorização de suas forças essenciais e, portanto, sua objetivação enquanto homem está limitada "por um elemento natural particular" (MARX, 1972, p. 82, tradução nossa). Consequentemente é ainda uma alienação determinada, particular do homem. Marx evidencia, além disso, que "a essência da riqueza não é, pois, um trabalho determinado, um trabalho ligado a um elemento particular, uma determinada manifestação do trabalho, mas sim o trabalho em geral” (MARX, 1972, p. 82, tradução nossa).

O que significa efetivamente que toda objetividade é, em potencial, objeto da exteriorização humana (ou, para os economistas, da produção de riqueza) e que os produtos dessa 
exteriorização se diferenciam cada vez mais do objeto natural. Em síntese, a alienação, como aparece nos trechos relacionados acima, diz respeito ao trabalho como produtor da riqueza exterior, que é o modo pelo qual ele é compreendido pela economia política.

Ainda no debate com os economistas, Marx resgata a relação entre o trabalhador e o produto do trabalho como ponto de partida para a análise da produção atual. A esse respeito ele afirma:

[...] a alienação (Entäusserung) do trabalhador em seu produto significa não só que o trabalho se transforma em objeto, assume uma existência externa (äussern), mas que existe independentemente, fora dele, é a ele estranho (fremd), e se torna um poder autônomo em oposição a ele, que a vida que deu ao objeto se torna uma força hostil e estranha. (MARX, 1972, p. 58, tradução nossa).

Marx identifica, portanto, a relação do trabalhador com o produto como uma relação de alienação. Esta aparece na citação acima com duplo significado: primeiro, o trabalho se transforma em objeto, assume uma existência externa, ou seja, no produto o trabalho se torna algo exterior. Segundo, o trabalho existe independente do trabalhador e se transforma em um "poder autônomo em oposição a ele". A alienação do trabalhador, portanto, aparece como uma forma peculiar da exteriorização humana na qual, ao mesmo tempo em que o trabalho é realizado enquanto exterioridade, se engendra uma relação de oposição entre produtor e produto. Essa relação manifesta uma tendência proporcionalmente antagônica entre eles. $O$ primeiro se empobrece cada vez mais, e o segundo se torna cada vez mais poderoso. Essa crescente divergência de sentido acaba por levá-los a se estranharem mutuamente, transformando a vida que o trabalhador deu ao objeto numa força hostil e estranha. Nessa análise, Marx se refere aos aspectos específicos da produção atual em que a objetivação humana se realiza como alienação, ou seja, como produção da riqueza exterior e se volta contra o homem que produz.

Para Marx, a economia política "só vê o lado positivo do trabalho" justamente porque "não consolida a relação direta entre o trabalhador (trabalho) e a produção" (MARX, 1972, p. 59, tradução nossa).

Vê-se, portanto, que a aproximação entre as categorias objetivação e alienação só corresponde à análise de Marx, nos Manuscritos, quando ele se reporta a crítica a Hegel e, de forma distinta, aos economistas. Ambos, guardadas as devidas diferenças, consideram o trabalho atual como forma universal da atividade humana. Os economistas partem explicitamente da 
produção atual considerando-a eterna; Hegel pretende voltar-se para a reprodução espiritual como locus, por excelência, da afirmação do homem. Mas Marx demonstra que toda tematização hegeliana está pautada na produção atual e, assim sendo, Hegel universaliza a alienação como forma de o homem se relacionar com a objetividade exterior e consigo mesmo.

Marx, de modo distinto, situa que a alienação é, de fato, atualmente, a forma de o homem se relacionar com sua produção, mas, para ele, a objetivação, tomada como forma geral de o homem se auto pôr, não tem semelhança necessária com a alienação. Mas, partindo da forma contemporânea de o homem se produzir, ele encontra não só uma relação de alienação, mas de inversão e antagonismo.

A alienação (Entäusserung), portanto, aparece como momento constitutivo no interior da produção atual, posto que nela "o objeto produzido pelo trabalho, seu produto, o afronta como ser estranho (fremdes wesen), como um poder independente do produtor" (MARX, 1972, p. 57, tradução nossa). Nessa situação a efetivação do trabalho "aparece como desefetivação do trabalhador, a objetivação como perda e servidão dos objetos, a apropriação como estranhamento (Entfremdung), como alienação (Entäusserung)" (MARX, 1972, p. 57 - tradução nossa).

Esse é o ponto de partida da análise de Marx na parte final do primeiro Manuscrito, onde pretende esclarecer as interconexões que a economia política (que ele havia investigado anteriormente) não consegue identificar. Para tanto, busca na relação imediata entre produtor e produto o passo inicial que vai levá-lo a demonstrar que, ao contrário do que acreditam os economistas, a "propriedade privada é [...] o resultado, a consequência necessária do trabalho alienado (entäusserten), da relação exterior (äusserlichen) do trabalhador com a natureza e consigo mesmo" (MARX, 1972, p. 57, tradução nossa). Marx chega, portanto, à propriedade privada como resultado "da análise do conceito de trabalho alienado (entäusserten), ou seja, do homem alienado (entäusserten), do trabalho tornado estranho (entfremdeten), da vida tornada estranha (entfremdeten), do homem tornado estranho (entfremdeten)" (MARX, 1972, p. 67, tradução nossa).

Pode-se dizer que, de acordo com as passagens acima, o trabalho alienado é anterior ao estranhamento. Não cronologicamente, nem de fato, mas analiticamente, como diz Marx. Ele identifica o trabalho alienado como relação exterior do trabalhador com a natureza e consigo mesmo e afirma que a propriedade privada é, primeiramente, fruto do homem alienado e, em seguida, também "do homem tornado estranho". O homem, o trabalho, a vida tornam-se estranhas 
a partir da alienação do produto e da atividade. Nesse sentido, a propriedade privada é o produto da atividade humana apartada do homem.

Marx demonstra assim que a propriedade privada é consequência do trabalho alienado afirmando, no entanto, que "mais tarde essa relação se transforma em ação recíproca" (MARX, 1972, p. 67, tradução nossa). E acrescenta:

Só no derradeiro ponto de culminação de desenvolvimento da propriedade privada que o mistério que lhe é próprio reaparece, a saber, por um lado, que ela é produto do trabalho alienado (entäusserten) e, por outro, que ela é o meio pelo qual o trabalho se aliena (entässert), a realização da alienação (Entäusserung). (MARX, 1972, p. 67, tradução nossa).

A questão, para Marx, é saber "como o homem vem a se alienar (entäussern), a se tornar estranho (entfremdeten) em relação a seu trabalho? Como se fundamenta este estranhamento (Entfremdung) na essência do desenvolvimento humano?” (MARX, 1972, p. 68 - tradução nossa). A resposta, segundo ele, só pode surgir a partir da compreensão da origem do homem (trabalho) e da propriedade privada como consequência da atividade humana: "Já demos um grande passo para a solução do problema", ele afirma, "transformando a questão da origem da propriedade privada naquela da relação do trabalho alienado (entäusserten) no desenvolvimento da humanidade" (MARX, 1972, p. 69 - tradução nossa).

A propriedade privada (estranhamento) surge, portanto, no interior desse processo, mas não é inerente a ele. Segundo Marx: "Quando se fala em propriedade privada pensa-se ter se ocupado de algo exterior ao homem. Quando se fala em trabalho, ocupa-se diretamente do próprio homem. Esta nova forma de colocar a questão já implica em sua solução” (MARX, 1972, p. 69, tradução nossa). O trabalho alienado é, portanto, a gênese da propriedade privada enquanto esta é o seu produto necessário, já que ele se realiza como exterioridade em relação ao homem. Desse modo, pode-se dizer, que utilizar "Entfremdung, Entäusserung" é uma forma de exprimir um movimento que tem no estranhamento (Entfremdung) sua expressão concreta e atual e, na alienação (Entäusserung), seu ponto de partida. Segundo Marx, a partir da relação exterior entre produto, produtor e produção se processa a relação de antagonismo entre eles.

Sem dúvida, trata-se aqui daquilo que Chasin (1995) reconheceu como a $3^{\mathrm{a}}$ crítica ontológica que instaura o pensamento próprio de Marx. Com efeito, distinguindo-se das interpretações correntes que concebem a análise marxiana como síntese entre filosofia hegeliana, 
socialismo francês e economia política clássica, Chasin demonstra, através do exame rigoroso dos textos (cartas, esboços, artigos etc.) do período de 1841 a 1847, que a abordagem do filósofo alemão se constrói como resultado de três críticas ontológicas, a saber: a crítica à política, à especulação hegeliana e, finalmente, à economia política. Nas duas primeiras, Marx inverte a relação determinativa entre estado e sociedade civil e entre pensar e ser, respectivamente. Enquanto na terceira situa o trabalho alienado como origem da propriedade privada, invertendo o polo de determinação da economia clássica. É exatamente o que Marx realiza no primeiro manuscrito: a denúncia de que a "economia política parte do fato da propriedade privada", sem explicá-lo, ao passo que ele demonstra, analiticamente, a gênese da propriedade privada na atividade humana considerando essa relação no processo de produção material atual.

A partir dessa compreensão, Marx denuncia a operação efetuada por Adam Smith que coloca o homem sob a determinação da propriedade privada ao incorporá-la a ele. A economia política, portanto, converte o homem, em essência da propriedade privada. Assim, a propriedade privada, que "antes era ser-exterior-a-si (Sichäusserlichsein), alienação (Entäusserung) real do homem, converteu-se apenas em ato de alienação (Entäusserung), em venda (Veräusserung)" (MARX, 1972, p. 80, tradução nossa).

$\mathrm{Na}$ versão dos economistas, portanto, os homens em sua atividade sensível apenas realizam a atividade da propriedade privada através da venda. Sabe-se já que o trabalho alienado produz a exterioridade da propriedade privada, ou que, através da alienação do trabalhador, a propriedade privada é produzida enquanto ser-exterior ao homem. Mas, para os economistas que reconhecem o trabalho como "essência subjetiva da riqueza no interior da propriedade privada", a alienação do trabalhador que produz um ser exterior a si não é mais que uma atividade da própria propriedade privada em seu movimento de se auto pôr: é o ato de alienação da propriedade privada, é venda.

Desse modo, a venda é o meio através do qual os homens se relacionam, e o seu trabalho se produz no interior do domínio da propriedade privada, quando a apropriação da objetividade exterior se realiza na relação de compra e venda.

O termo Veräusserung - venda - aparece nas anotações de 1844 apenas em dois momentos. Além do descrito acima, na abordagem sobre o dinheiro, Marx conclui: “a força divina do dinheiro repousa em sua essência enquanto ser genérico, estranhado (entfremdeten), 
alienante (entäussernden), na qual o homem se vende (veräussernden). O dinheiro é a capacidade (Vermögen) alienada (entäusserte) da humanidade” (MARX, 1972, p. 122, tradução nossa).

Em resumo, pode-se dizer que Entäusserung e Entfremdung não são simplesmente sinônimos ${ }^{1}$, como acreditam alguns ${ }^{2}$. Tampouco aparecem como categorias contrapostas como

${ }^{1}$ Essa diferença não passou desapercebida por autores mais cuidadosos. Entre eles, Mézsáros em seu Marx: teoria da alienação, afirma: "Em alemão, as palavras Entäusserung, Entfremdung e Veräusserung são usadas para significar 'alienação' ou 'alheamento'. Entäusserung e Entfremdung são usadas com muito maior frequência por Marx do que Veräusserung, que é, como Marx a define, 'die Praxis der Entäusserung' (a prática da alienação) ou, em outro trecho, 'Tat der Entäusserung' (o ato da alienação). Assim Veräusserung é o ato de traduzir na prática (na forma da venda de alguma coisa) o princípio da Entäusserung. No uso que Marx faz do termo, 'Veräusserung' pode ser intercambiado com 'Entäusserung' quando um 'ato' específico ou uma 'prática' específica são referidos [...] Tanto Entfremdung como Entäusserung possuem uma tripla função conceitual: a) a referida a um princípio geral; b) expressão de um estado de coisas dado, e c) indicação de um processo que domina esse estado. Quando a ênfase recai sobre a 'externalização' ou 'objetivação', Marx usa a palavra Entäusserung (ou palavras como Vergegenständlichung), ao passo que Entfremdung é usada quando a intenção do autor é ressaltar o fato de que o homem está encontrando oposição por parte de um poder hostil, de sua própria criação". (MÉZSÁROS, 1981, p. 281). José Paulo Netto se reporta à citação acima, chamando a atenção para o problema: "Não me deterei aqui nos importantes aspectos filológicos que envolvem a terminologia que comparece no tratamento e na colocação do problema [da alienação]. No que concerne ao emprego, por Marx, em 1844, de Entäusserung, Entfremdung $e$ Veräusserung (traduzidos preferentemente por alienação e também por estranhamento) remeto simplesmente à observação de Mészáros". (NETTO, 1981, p. 18). Também em nota, Celso Frederico observa: "Antes de prosseguir faz-se necessário um esclarecimento conceitual. Marx utiliza dois termos em alemão para referir-se à situação do trabalho no mundo capitalista: Entäusserung (alienação) e Entfremdung (estranhamento), por conta de traduções descuidadas, popularizou-se a expressão 'trabalho alienado'. Marx, entretanto, ora empregava as duas expressões indistintamente, ora acenava para uma sutil diferença. A referência ao trabalho estranhado, visando ressaltar a oposição entre o operário e a sua criação, que lhe aparece como um poder irreconhecível e hostil, parece propor um distanciamento em relação à teoria feuerbachiana da alienação religiosa, ao mesmo tempo em que realça a dominação social inscrita no processo de produção, diferenciando-a, portanto, daquela alienação que é um produto abstrato, espiritual, da consciência mistificada" (FREDERICO, 1995, p. 77). Lucien Sève, em Análises Marxistas da Alienação, referindo-se especificamente às obras de maturidade de Marx, considera que "quanto à significação específica de cada um dos termos que compõem este vocabulário da alienação, creio ser possível avançar com prudência, pois trata-se de uma questão das mais complexas, a seguinte hipótese geral. As palavras da família de äusser, externo, exterior, marcadas por esta significação de base, são a maior parte das vezes empregadas por Marx, quer para designar a simples desapropriação de um bem pelo ato de venda (em regra geral: Veräusserung), quer para anotar o processo mais profundo de tornar-exterior, quanto processo separante, opondo mesmo as coisas, ou as relações e as formas enquanto tomam a feição de coisas. Aí está um primeiro aspecto da concepção madura da alienação: com o vocabulário de Entäusserung, estamos essencialmente no terreno da reificação, da autonomização e da esclerose das formas em relação à sua essência, do fetichismo. Sobre este ponto é característico que na Contribuição, onde ainda só o movimento das mercadorias e do dinheiro é tratado, aparece unicamente o vocabulário da Ver - Entäusserung. As palavras da família de fremd (por exemplo na expressão constante: fremde Arbeit, trabalho de outrem) introduzem uma outra dimensão da alienação: a das relações entre as pessoas, os indivíduos sociais, que encobrem as relações entre as classes. Com o vocabulário de Entfremdung estamos no terreno da desapropriação, do despojamento, da sujeição dos homens aos produtos da sua atividade tornados força estranha e tomando a forma da dominação de uma classe exploradora. Apreendemos ao vivo o elo ao mesmo tempo semântico e teórico entre fremd e Entfremdung que carcacteriza o processo de alienação enquanto este afeta os homens. (SÈVE, 1975)

${ }^{2}$ Bottigelli, na tradução francesa (MARX, 1972, p. 56), afirma em uma nota: "Marx emprega aqui o termo Entfremdung. Mas ele utiliza também, quase com a mesma frequência, Entäusserung. Etimologicamente, a palavra Entfremdung incide mais sobre a idéia de estranhar enquanto Entäusserung marca mais a ideia de despossuir. De nossa parte renunciamos a levar em conta uma nuance que Marx não considera, já que emprega indiferentemente os dois termos. Hegel não fazia essa diferença e nos parece inútil recorrer ao procedimento de Hippolyte que cria, na

Sapere aude - Belo Horizonte, v. 9 - n. 18, p. 61-78, jul./Dez. 2018 - ISSN: 2177-6342 
sugere Lukács. A Entäusserung se refere mais diretamente a uma relação de separação, enquanto a Entfremdung traduz uma relação de antagonismo. Ambas, no entanto, compõem o movimento do trabalho humano que se exerce no interior da propriedade privada. Portanto, nem uma nem outra aparecem como uma necessidade do trabalho. Mas o antagonismo, expresso por Marx como Entfremdung - estranhamento, surge da separação que ele identifica como Entäusserung alienação. Neste contexto, a Veräusserung - venda - seria uma categoria mediadora entre a exteriorização que se realiza como alienação e o estranhamento, ou seja, a venda transforma a exteriorização da vida (Lebensäusserung) em alienação da vida (Lebensentäusserung), duas expressões contrapostas.

\section{CONCLUSÃO}

De modo geral - e abstratamente considerado - o avanço da propriedade privada em direção à sua forma plena está em consonância com a autoconstrução humana, pois possibilita ao homem tornar-se objeto de sua própria consciência sensível e torna o carecimento carecimento humano. Mas, se se leva em conta a existência humana efetiva no interior da dominação da propriedade privada, esse avanço implica necessariamente, ao mesmo tempo, um recuo em termos do domínio do homem sobre si. Somente no movimento de produção e superação da propriedade privada e dos estranhamentos gerados por esta forma de atividade, pode-se vislumbrar o homem efetivo como ser para si. A necessidade de superação da propriedade privada é, por conseguinte, a necessidade de o homem resgatar sua própria existência efetiva.

Marx, já nessa época, concebe tal movimento como ato consciente e efetivo dos homens que exercem efetivamente a atividade humana. Ele diz ao final do Primeiro Manuscrito:

\footnotetext{
Da relação do trabalho estranhado com a propriedade privada, resulta que a emancipação da sociedade da propriedade privada, da servidão etc. se exprime sob a forma política da emancipação dos trabalhadores, não porque se trata unicamente de sua emancipação, mas porque implica na emancipação universal dos homens, uma vez que toda servidão humana está implicada na relação do trabalhador com a produção e que todas as relações de servidão não são senão variantes e consequências desta relação. (MARX, 1972, p. 68, tradução nossa).
}

sua tradução da Fenomenologia, a palavra extraneation. Onde Marx, insistentemente, utiliza sucessivamente os dois termos, nós traduzimos um dos dois por dessaisissement. Quando Marx utiliza o adjetivo entfremdet, nós traduzimos, sempre que possível, por tornar estranho (rendu étranger). Mas o termo alienação (aliené) não está reservado unicamente para tornar entäussert". 
Quando Marx ressalta a "forma política", refere-se a um modo social de existência onde há dominação. Mas trata-se nesse caso da dominação do trabalho, ou seja, do homem sobre a matéria morta. Não há nenhuma relação desse modo social (que ainda necessita da forma política) com o estado burguês que responde necessariamente pelo interesse da apropriação privada. A emancipação política dos trabalhadores representa o primeiro momento do resgate efetivo do homem como ser-para-si, pois implica retomar o trabalho como categoria original da vida social. Dessa forma, pode-se afirmar que o mundo humano não subsiste sem trabalho, mas tem a possibilidade de existir sem propriedade privada. Os trabalhadores aparecem, nesse contexto, como porta-vozes da humanidade, até que possam desaparecer nos limites dessa abstração e renascer como homens concretos.

Na citação reproduzida acima, Marx salienta também que todas as relações de servidão humanas são variantes e consequências da relação do trabalhador com a produção. Sabe-se que os estranhamentos se expandem a todos os campos da vida humana, e sua gênese acaba por se perder na indeterminação do complexo societário. A relação do trabalhador com a produção é a relação do homem que engendra sua própria existência a partir de sua humanidade e, por conseguinte, afirmar que todos os estranhamentos encontram sua base nessa relação é afirmar que o fundamento da vida humana é a própria existência concreta e efetiva dos homens. Consequentemente, a superação dos estranhamentos pressupõe a superação da forma de existência que os engendra.

Mas, em consonância com o pensamento marxiano, o movimento de superação da propriedade privada não se constitui como autônomo e independente dos homens como o movimento de formação da propriedade privada em-si. Ao contrário, ele é o resgate consciente do mundo humano para o homem. Convém insistir que, por mais que as condições objetivas possibilitem tal resgate, em si mesmas elas não são suficientes para levá-lo a cabo. O movimento de superação dos estranhamentos implica, enquanto ato consciente, em reflexão teórica. 


\section{REFERÊNCIAS}

CHASIN, José. Marx: Estatuto Ontológico e Resolução Metodológica. In: TEXEIRA, Francisco. Pensando com Marx São Paulo: Ensaio, 1995.

CHASIN, José. Ad Hominem - Rota e Prospectiva de um Projeto Marxista. In: Ensaios Ad Hominem 1, tomo I, SP: Ad Hominem,1999.

COSTA, Monica Hallak Martins. As categorias Lebensäusserung, Entäusserung, Entfremdung e Veräusserung nos Manuscritos Econômico-filosóficos de Karl Marx de 1844. Belo Horizonte. Faculdade de Filosofia e Ciências Humanas da UFMG Dissertação de Mestrado (Filosofia), 1999.

FREDERICO, Celso. O jovem Marx (1843-44: origens da ontologia do ser social). São Paulo: Cortez, 1995.

LUKÁCS, György. Os princípios ontológicos fundamentais em Marx. Tradução Carlos Nelson Coutinho. São Paulo: Ed. Liv. Ciências Humanas, 1979.

MARX, Karl. Manuscrits de 1844 (Économie politique e philosophie). Tradução Emile Bottigelli. Paris: Ed. Sociales, 1972.

MARX, Karl. Ökonomisch-philosophische Manuskripte aus dem jahre 1844. Berlim: Dietz Verlag, 1985.

MARX, Karl. Prefácio a Para a crítica da economia política. Tradução José Arthur Gianotti. Coleção: Os Pensadores vol. XXXV. São Paulo: Abril Cultural, 1974.

MÉZSÁROS, Istvan. Marx: a teoria da alienação. Tradução Valtensir Dutra. Rio de Janeiro: Zahar editores, 1981.

NETTO, José Paulo. Capitalismo e reificação. São Paulo: Livraria Editora Ciências Humanas, 1981.

RUBEL, Maximilian. Crônica de Marx São Paulo: Ensaio, 1991.

SANTOS, José Henrique. Trabalho e riqueza na Fenomenologia do espírito de Hegel. São Paulo, Loyola, 1993.

SÈVE, Lucien. Análises marxistas da alienação. Tradução Madalena Cunha Matos. Lisboa: Edições Mandacaru, 1975. 